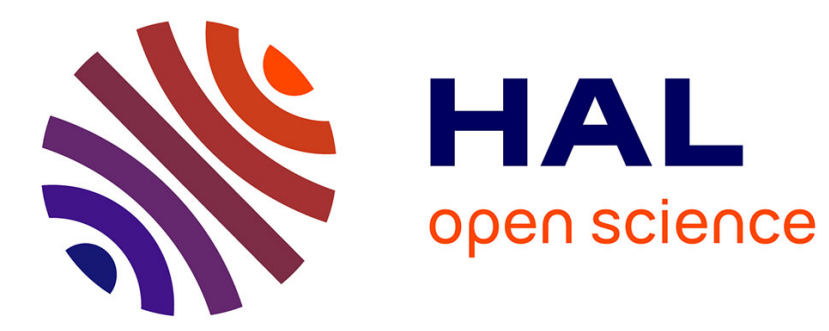

\title{
Population dynamics of brown trout, Salmo trutta L., in a tributary in Brittany (France): spawning and juveniles
}

Jean-Luc J.-L. Baglinière, Gérard Maisse, Pierre-Yves Le Bail, A. Nihouarn

\section{To cite this version:}

Jean-Luc J.-L. Baglinière, Gérard Maisse, Pierre-Yves Le Bail, A. Nihouarn. Population dynamics of brown trout, Salmo trutta L., in a tributary in Brittany (France): spawning and juveniles. Journal of Fish Biology, 1989, 34, pp.97-110. 10.1111/j.1095-8649.1989.tb02960.x . hal-02728827

\section{HAL Id: hal-02728827 \\ https://hal.inrae.fr/hal-02728827}

Submitted on 2 Jun 2020

HAL is a multi-disciplinary open access archive for the deposit and dissemination of scientific research documents, whether they are published or not. The documents may come from teaching and research institutions in France or abroad, or from public or private research centers.
L'archive ouverte pluridisciplinaire HAL, est destinée au dépôt et à la diffusion de documents scientifiques de niveau recherche, publiés ou non, émanant des établissements d'enseignement et de recherche français ou étrangers, des laboratoires publics ou privés. 


\title{
Population dynamics of brown trout, Salmo trutta $\mathrm{L}$. , in a tributary in Brittany (France): spawning and juveniles
}

\author{
J. L. BagliniÈre*, G. Maisse*, P. Y. Lebail* and A. Nihouarn $\dagger$ \\ * Station de Physiologie et d'Ecologie des Poissons, INRA, 65 Rue de St Brieuc, 35042 \\ RENNES CEDEX, France and †Conseil Supérieur de la Pêche, 84 Rue de Rennes, 35510 \\ CESSON SEVIGNE, France
}

(Received 11 May 1987, Accepted 23 August 1988)

\begin{abstract}
The colonization by both resident and migrating spawner populations of brown trout and the characteristics of resident and migrating juveniles derived from the two populations have been studied in a brook and its tributary over 4 years. Resident trout spawns mainly in the upstream part of the brook and migrating trout in the downstream part. There are density and growth variations for the two age classes $(0+$ and $\mathrm{I}+$ ) of juveniles in autumn according to the year and the environment. In the brook, the population of $0+$ fish increases from downstream to upstream while the density of other age classes decreases. The migrating juvenile population of the brook changes annually and consists mainly of $1 \mathrm{~s}$ (one summer) individuals coming from the upper part. These individuals migrate generally in autumn and winter while young trout produced in the middle and downstream parts of the brook migrate mainly in the spring. The emigration process of the $0+$ population decreases markedly from upstream to downstream and appears to be independent of the autumn length and sex ratio. In the tributary, most trout are $0+$ years old, the population structure is different, and no migrating fish is observed. The results are discussed and a colonization strategy of the brown trout population in this brook is suggested.
\end{abstract}

\section{INTRODUCTION}

Since 1974, brown trout, Salmo trutta L., populations have been studied in the River Scorff in Brittany (Euzenat \& Fournel, 1976; Baglinière, 1979; Baglinière et al., 1979; Nihouarn, 1983). In one of its tributaries, the Kernec brook, some observations have shown the presence of a resident population and a migrating population coming from the river and spawning in the brook, but the interaction between these two populations had never been studied.

In 1977 a more precise study was begun to examine the influence of each group of spawners on the population dynamics. Their characteristics were compared in earlier previous reports (Maisse et al., 1987; Baglinière et al., 1987) which showed that (1) the spawners born in the brook stayed there during their entire life-span while the migrating trout came back to the river after spawning; (2) the upstream activity of migrating spawners was connected mainly with the strong spates; (3) in both populations, males were more numerous and younger than the females, the $1+$ females being less well represented in migrating spawners than in the tributary adult population which had a slower growth rate; (4) in the brook, $1+$ spawners were those having the best $0+$ growth rate; (5) the reproductive potential of migrating spawners could be smaller than that of the tributary spawners. The final part of that study is presented here. It shows the distribution of the two components of the population in the tributary during spawning. Furthermore, the characteristics of migrating and resident juveniles, with the influence of autumn 


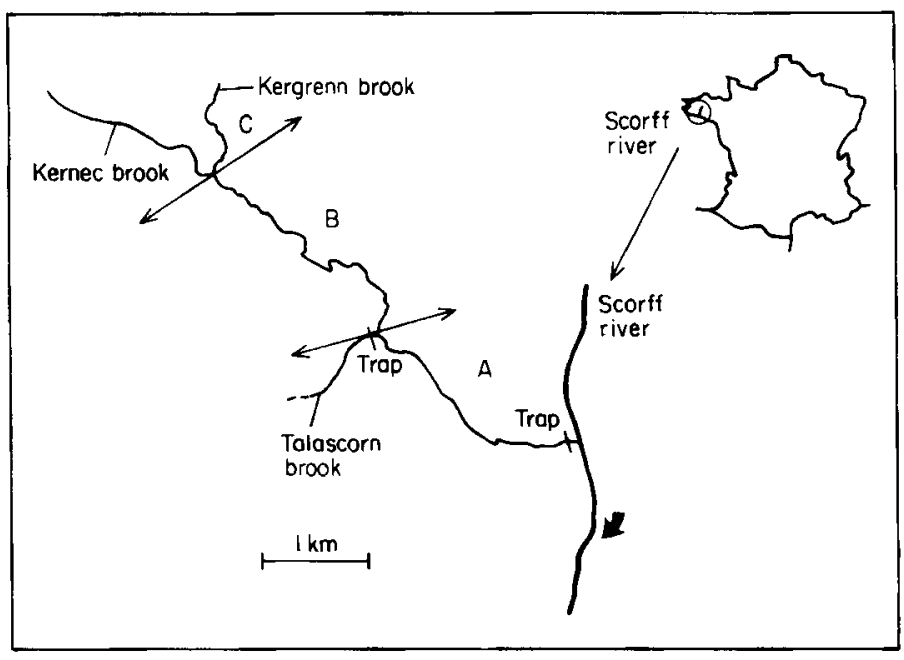

Fig. 1. Map showing location of Kernec brook and its tributary.

length and distribution upon their later life, are studied. Although the stockrecruitment relationship was not studied, the colonization strategy of trout in the brook and its tributary was investigated.

\section{MATERIALS AND METHODS}

The present study was made in Kernec brook (Fig. 1), a right bank tributary of the downstream part of the River Scorff. This brook has two tributaries, one in the middle part (Talascorn brook) and another in the upper part (Kergrenn brook). Kernec brook was divided into three large zones (downstream to upstream: A, B, C) whose habitat characteristics and those of Talascorn brook have been described (Table 1).

All trout caught (by electrofishing and by trapping) were measured (fork length). Age was determined from scale reading and/or the Petersen method. In migrating juveniles, age classes were designated by cohort from the number of summer seasons, e.g. one summer (1s) included $0+, 1$ and $1+$ classes and two summers $(2 s) 1+, 2$ and $2+$.

Some fish were killed in the 1s migrating $(1983,1984)$ and $1+$ resident $(1984$, zone B) populations for sex determination.

Three investigations were carried out:

1. The distribution of the two components of the trout population during spawning. From 1977 to 1980 , migrating spawners were tagged with Carlin or Floy-tags to determine their most upstream position in the tributary during the spawning period. In 1977-1978 and 1980-1981, redds were counted and mapped (no. $\mathrm{km}^{-1}$ ) throughout the spawning period in zones $\mathrm{A}$ and $\mathrm{B}$.

2. The autumn characteristics of the whole $0+$ juvenile population. The population of $0+$ juveniles was estimated in autumn by electrofishing (twice using Seber-Le Cren method): each year in Talascorn brook $\left(600 \mathrm{~m}^{2}\right)$ and in zones $A$ and $B\left(6736 \mathrm{~m}^{2}\right)$; and in small representatives sectors of zone C in $1982\left(211 \mathrm{~m}^{2}\right)$ and $1983\left(312 \mathrm{~m}^{2}\right)$, where the whole $0+$ population was estimated by multiplying the density in sectors by the total water area of the zone.

3. The later stage of $0+$ juveniles. The later stage of $0+$ juveniles was checked either by electrofishing in autumn or by trapping during their downstream migration in both brooks. In 1983 the 0 + juveniles caught in autumn in Kernec brook were marked variously (Table II) according to their size (the length of $80 \mathrm{~mm}$ was used because the results from previous 


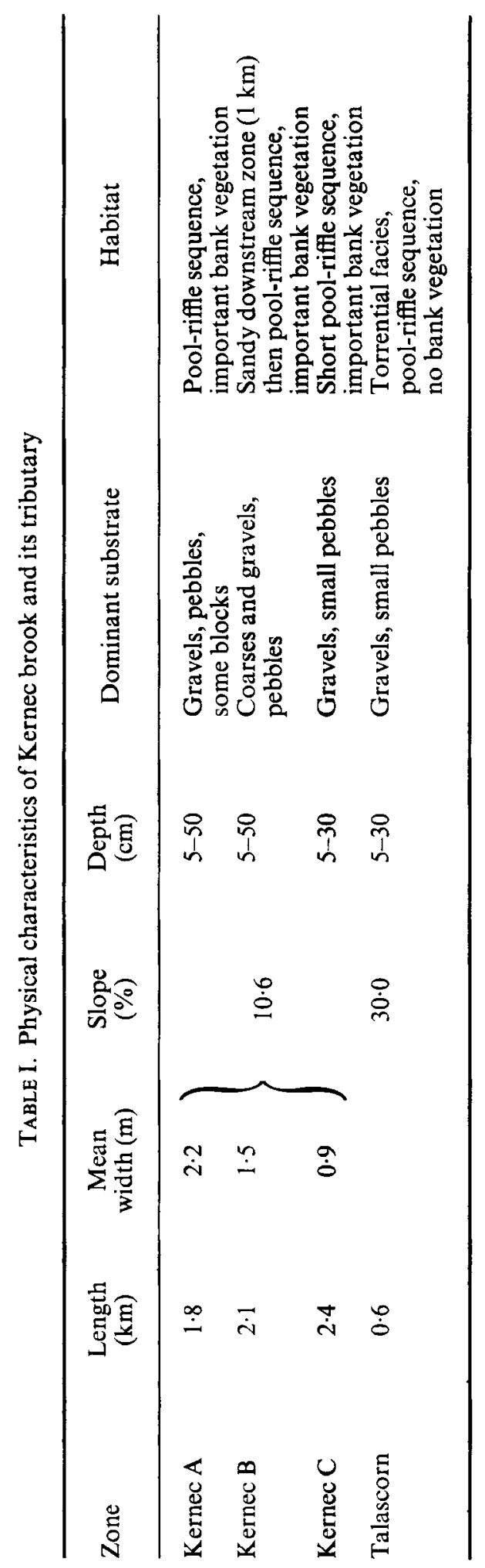


TABLE II. Identification by fin-clipping $(+)$ of groups of trout $0+$ caught by electrofishing in Kernec brook according to autumn fork length and distribution

\begin{tabular}{lccccc}
\hline & & \multicolumn{4}{c}{ Fin clipped } \\
\cline { 3 - 6 } $\begin{array}{l}\text { Zone of } \\
\text { catch }\end{array}$ & $\begin{array}{c}\text { Length } \\
\text { group (mm) }\end{array}$ & Adipose & $\begin{array}{c}\text { Right } \\
\text { ventral }\end{array}$ & $\begin{array}{c}\text { Left } \\
\text { ventral }\end{array}$ & $\begin{array}{c}\text { Name of } \\
\text { group }\end{array}$ \\
\hline A & $<80$ & - & + & - & A inf. \\
& $\geq 80$ & - & - & + & $\begin{array}{c}\text { A sup. } \\
\text { B inf. }\end{array}$ \\
B & $<80$ & + & + & - & B sup. \\
C & $\geq 80$ & + & - & + & C \\
\hline
\end{tabular}

years had shown that the size mode was located between 70 and $80 \mathrm{~mm}$ ) and location, to analyse the influence of these two parameters on their later stage. They were recaptured by trapping and electrofishing (May 1984 at the end of migration) in zones A and B.

Data were analysed by standard statistical methods ( $\chi^{2}$, Student's $t$-test, analysis of variance, simple correlation) with $95 \%$ confidence limits.

\section{RESULTS}

\section{SPAWNING}

In 1977, spawning began principally in the upper part of zone B with resident spawners, as there were no migrating spawners at this period. When the latter migrated in the brook, zone A was used first then spawning gradually spread upstream. The upper part of zone B and lower part of zone A were the most frequented.

In 1980, spawning began when some migrating spawners were already present in the brook. In contrast to 1977 , spawning began first in zone $A$ then extended upstream. At the end of December the number of redds in zone B (at $c .3$ and $4 \mathrm{~km}$ from the trap) increased, while the number of migrating females remained the same. Then, as the number of these females increased, a larger number of redds was observed in the downstream part of zone $A$.

Most tagged migrating spawners were present in zone A but some of them were seen as far as the upstream part of zone B. No tagged fish were observed in the downstream part of zone $C$ where spawning grounds are used each year. Throughout the period of study, electrofishing surveys were done after strong spates, above the trap, along the length of zone A. During these surveys, very few resident spawners were observed.

\section{$0+$ JUVENILES IN AUTUMN}

The number, density and proportion of $0+$ fish increased from zone A (downstream) to zone C (upstream) in Kernec brook (this tendency was very strong in some years; about nine-fold in 1982 (Table III, Fig. 2)). In Talascorn brook, this age class was always dominant. Annual variations of density were large in the four 


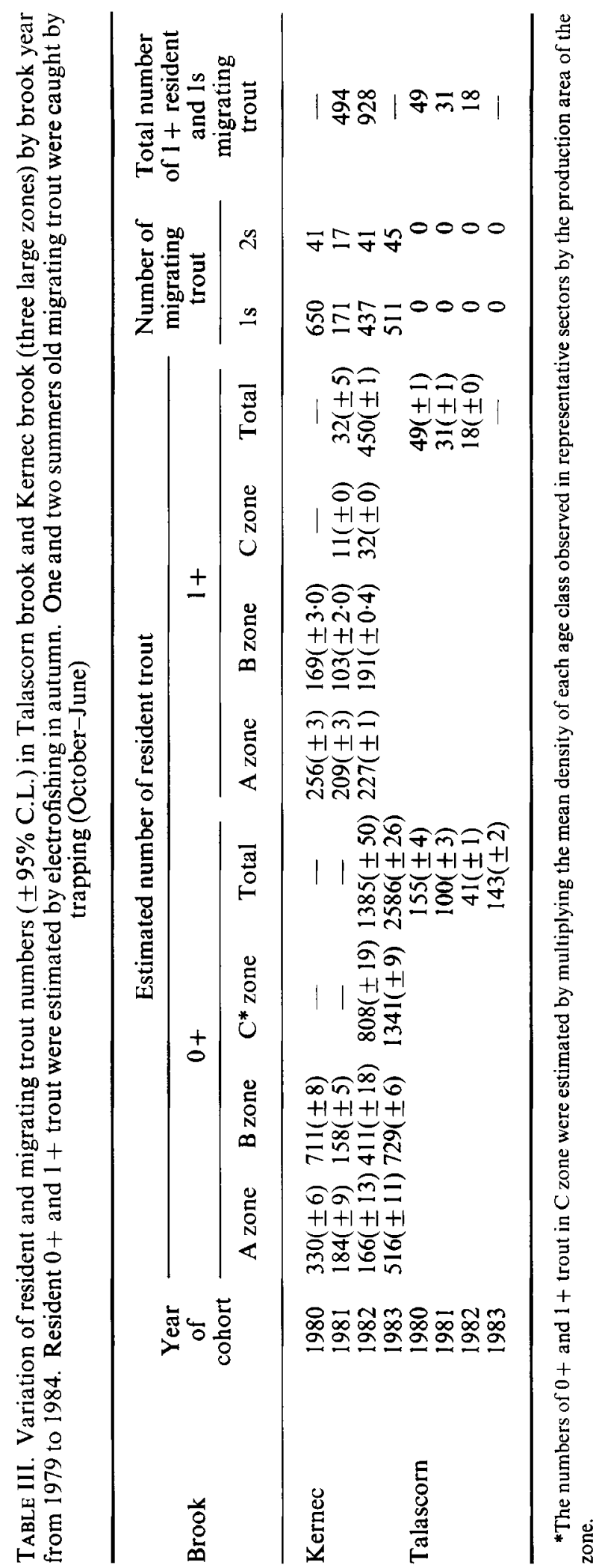



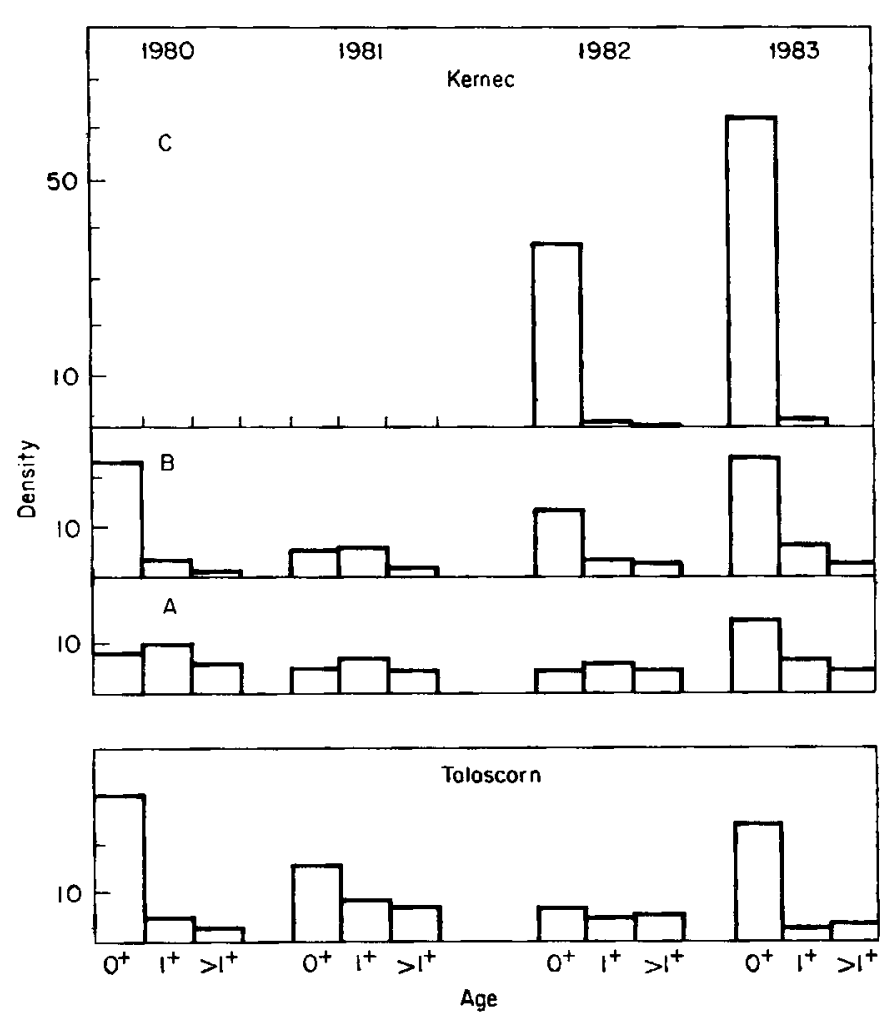

F1G. 2. Density (individuals $100 \mathrm{~m}^{-2}$ ) of trout age classes caught by electrofishing in Kernec (zones A, B and C) and Talascorn brooks, $1980-1983$.

environments studied: the lowest densities were observed in 1981 and 1982 and the highest during 1983.

Mean length changed according to year and environment $(P<0.01)$, it being almost always lower in Talascorn brook (Table IV). There were negative correlations between density and growth in zone A $(r=-0.910, P<0.05)$, zone $\mathrm{B}$ $(r=-0.890, P<0.05)$ and in Talascorn brook $(r=-0.978, P<0.01)$.

\section{LATER LIFE STAGE OF $0+$ JUVENILES}

Density and proportion of $1+$ resident fish increased from zone $C$ (upstream) where this age class was poorly represented to zone A (downstream) (Table III, Fig. 2). Annual density variations of $1+$ trout were small and very similar in the four zones. Mean length changed according to year, zone and brook $(P<0 \cdot 05$, Table IV), highest in zone $\mathbf{B}$ and lowest in Talascorn brook. There was a negative correlation between density and growth only in zone $\mathrm{A}(r=-0.955, P<0.05)$. For each cohort, production of $1+$ fish was strongly correlated with that of $0+$ fish in zone A $(r=0.957, P<0.02)$ and in Talascorn brook $(r=0.990, P<0.01)$, but no correlation was observed in zone B.

No downstream movement of migrating juveniles was observed in Talascorn brook during the period of study. The annual number of migrating juveniles in Kernec brook varied from 188 to 691 fish (Table III), most of them (90\%) being one summer old (length $52-170 \mathrm{~mm}$ ). The other part of the population was two 
TABLE IV. Mean length ( $\pm 95 \%$ C.L. $)$ of $0+$ and $1+$ trout population caught in autumn in Kernec and Talascorn brooks, 1980-1983

\begin{tabular}{lccc}
\hline & & \multicolumn{2}{c}{ Mean length $(\mathrm{mm})$} \\
\cline { 3 - 4 } Zone & Year & $0+$ & $1+$ \\
\hline Kernec A & 1980 & $77( \pm 1 \cdot 3)$ & $138( \pm 1 \cdot 6)$ \\
& 1981 & $81( \pm 1 \cdot 4)$ & $149( \pm 2 \cdot 3)$ \\
& 1982 & $83( \pm 1 \cdot 6)$ & $149( \pm 2 \cdot 6)$ \\
& 1983 & $76( \pm 1 \cdot 0)$ & $148( \pm 2 \cdot 0)$ \\
Kernec B & 1980 & $81( \pm 0 \cdot 9)$ & $150( \pm 3 \cdot 1)$ \\
& 1981 & $89( \pm 1 \cdot 5)$ & $163( \pm 3 \cdot 2)$ \\
& 1982 & $82( \pm 1 \cdot 2)$ & $159( \pm 3 \cdot 4)$ \\
Kernec C & 1983 & $74( \pm 0 \cdot 8)$ & $152( \pm 2 \cdot 7)$ \\
& 1982 & $72( \pm 2 \cdot 2)$ & $160( \pm 0 \cdot 0)$ \\
Talascorn & 1983 & $78( \pm 1 \cdot 3)$ & $145( \pm 1 \cdot 1)$ \\
& 1980 & $68( \pm 1 \cdot 2)$ & $123( \pm 5 \cdot 1)$ \\
& 1981 & $70( \pm 1 \cdot 3)$ & $124( \pm 3 \cdot 9)$ \\
& 1982 & $74( \pm 3 \cdot 1)$ & $113( \pm 4 \cdot 8)$ \\
& 1983 & $69( \pm 1 \cdot 6)$ & $11( \pm 5 \cdot 0)$ \\
\hline
\end{tabular}

TABLE V. Percentage ( $\pm 95 \%$ C.L.) of female trout sampled by trapping in migrating 1s population in 1983 and 1984 , and in $1+$ resident population of zone $B$ of Kernec brook by electrofishing in 1984

\begin{tabular}{lcc}
\hline & \multicolumn{2}{c}{ Percentage of females } \\
\cline { 2 - 3 } & 1s migrating population & $1+$ resident population \\
\hline 1983 & $74( \pm 18)$ & - \\
1984 & {$[17 / 23]^{*}$} & $41( \pm 15)$ \\
& $52( \pm 19)$ & {$[17 / 41]$} \\
\hline
\end{tabular}

*Numbers of females/number of females and males in brackets.

summers old (length $112-210 \mathrm{~mm}$ ). Numbers of both age classes varied in the same way (no significant correlation). The sex ratio of the $1 \mathrm{~s}$ population favoured females in 1983 and contained equal numbers of males and females in 1984 (Table V). Migration of the 1s population took place from September or October to May or June according to the year. Migration activity was similar throughout the 4 years and greatest from March to May [Fig. 3(A)]. There was a significant correlation between number of zone $\mathrm{B} 0+$ trout and number of $1 \mathrm{~s}$ migrating juveniles $(r=0.92, P<0.05$, Table III). No correlation between these two parameters was observed for zone A. 

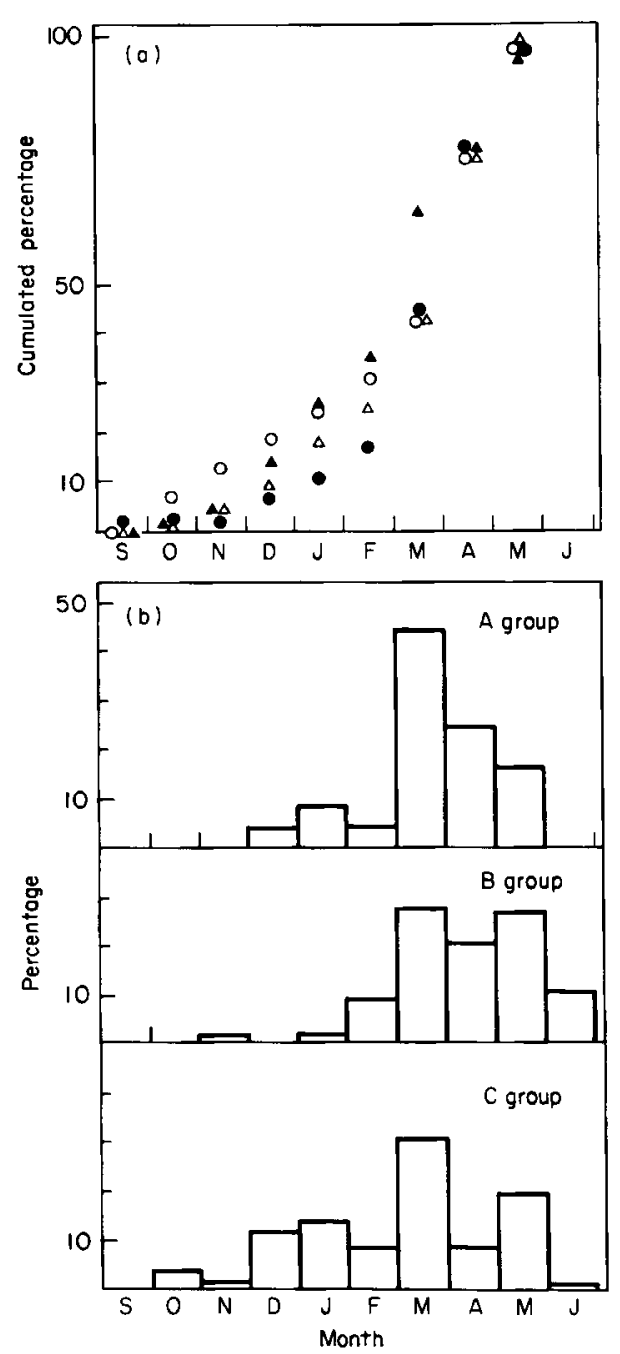

FIG. 3. Monthly evolution of number of migrating Is trout caught by trapping in Kernec brook. (a) Annual variation (cumulative percentage) from 1980 to $1984(0$, year $1980-81, n=650 ; 0,1981-82, n=171$; $\triangle, 1982-83, n=437 ; \Delta, 1983-84, n=432$ ). (b) Distribution (in percentage) of different tagging groups of $0+$ trout recaptured by trapping during 1983-84 downstream migration (A group, $n=25$; B group, $n=54$; C group, $n=432$ ).

Of the $27210+$ trout tagged in autumn, 1273 were recaptured by trapping and electrofishing at the $1 \mathrm{~s}$ or $1+$ stage (Table VI). The percentage of recaptured fish was higher in the original tagging zone for group A (84\%) and for group B (69\%) than for group C $(55 \%)$. The latter group represented $84 \%$ of all the migrating juveniles. The percentage and the distribution of 1 s or $1+$ recaptured trout did not change for groups $A$ and $B$ in relation with the length of $0+$ fish. The sex ratio of $1+$ resident trout recaptured in zone $\mathbf{B}$ did not differ significantly from equality $(P<0.66$, Table V) and was the same for both $B$ sup. and $B$ inf. groups. Whatever the tagged group, the bulk downstream migration of $1 \mathrm{~s}$ trout took place in March. However, the migration activity was different according to the tagged group 
TABLE VI. Distribution ( $\%$ ) of $0+$ trout population tagged according their autumn geographical location and recaptured at stage $1 \mathrm{~s}$ by trapping, or $1+$ by electrofishing, in zones A and B of Kernec brook

\begin{tabular}{lcccc}
\hline & \multicolumn{4}{c}{ Tagging group at 0+ stage } \\
\cline { 2 - 5 } & A & B & C & Total No. \\
\hline $\begin{array}{l}\text { Number of 0+ } \\
\text { tagged trout } \\
\text { \% and (number) recaptured }\end{array}$ & 500 & 723 & $1498^{*}$ & 2721 \\
at 1s or 1+ stage & 41 & 39 & 53 & \\
Zone of recapture & $(204)$ & $(281)$ & $(788)$ & $(1273)$ \\
at 1s or 1 + stage & & & & \\
B & $4 / 2$ & $69 / 52$ & $21 / 46$ & 370 \\
$\quad$ A & $84 / 44$ & $12 / 8$ & $24 / 48$ & 392 \\
Trap & $12 / 5$ & $19 / 11$ & $55 / 84$ & 511 \\
\hline
\end{tabular}

*Value includes the number of $0+$ trout estimated in zone $C$ and the number of $0+$ trout having escaped the electrofishing in zones $\mathrm{A}$ and $\mathrm{B}$.

$\dagger$ In the $x / y$ notation, $x=\%$, within tagging group, recaptured at each locality, and $y=\%$, at each recapture locality, of fish from each tagging group.

$\left[P<10^{-3}\right.$, Fig. 3(b)]. Group C migrated more in autumn and winter while groups $\mathrm{A}$ and $\mathrm{B}$ ran down mainly in spring.

\section{DISCUSSION}

The results of this study show several main aspects of the colonization strategy of trout in the small brook.

\section{SPAWNING OF MIGRATING AND RESIDENT TROUT}

There is a spatial segregation of two spawner populations in the brook during the reproduction period, migrants spawning mainly in the downstream part and residents in the upstream part. This can be explained by (a) the presence of suitable spawning ground only in the lower and upper reaches of the brook; (b) the upstream migration of resident spawners in the brook (Solomon \& Templeton, 1976), such movement being noted each autumn during electrofishing; (c) a late upstream movement of migrating females (Bagliniére et al., 1987), most of them being ripe and the journey made in the brook before spawning being short. However, the degree of segregation can change according to the occurrence of conditions favourable to the run of migrating spawners. Segregation results in a better use of the brook by decreasing competition for spawning grounds. This will lead to increase in the fry survival rate which is density-dependent (Chapman, 1966; Elliott, 1985).

\section{RECRUITMENT OF TWO JUVENILE POPULATIONS}

Eighty four percent of $1 \mathrm{~s}$ migrating juveniles and $42 \%$ of $1+$ resident trout recaptured in zones A and B belonged to group C. However, the percentage of recapture of that group was certainly overestimated, while that of the two other 

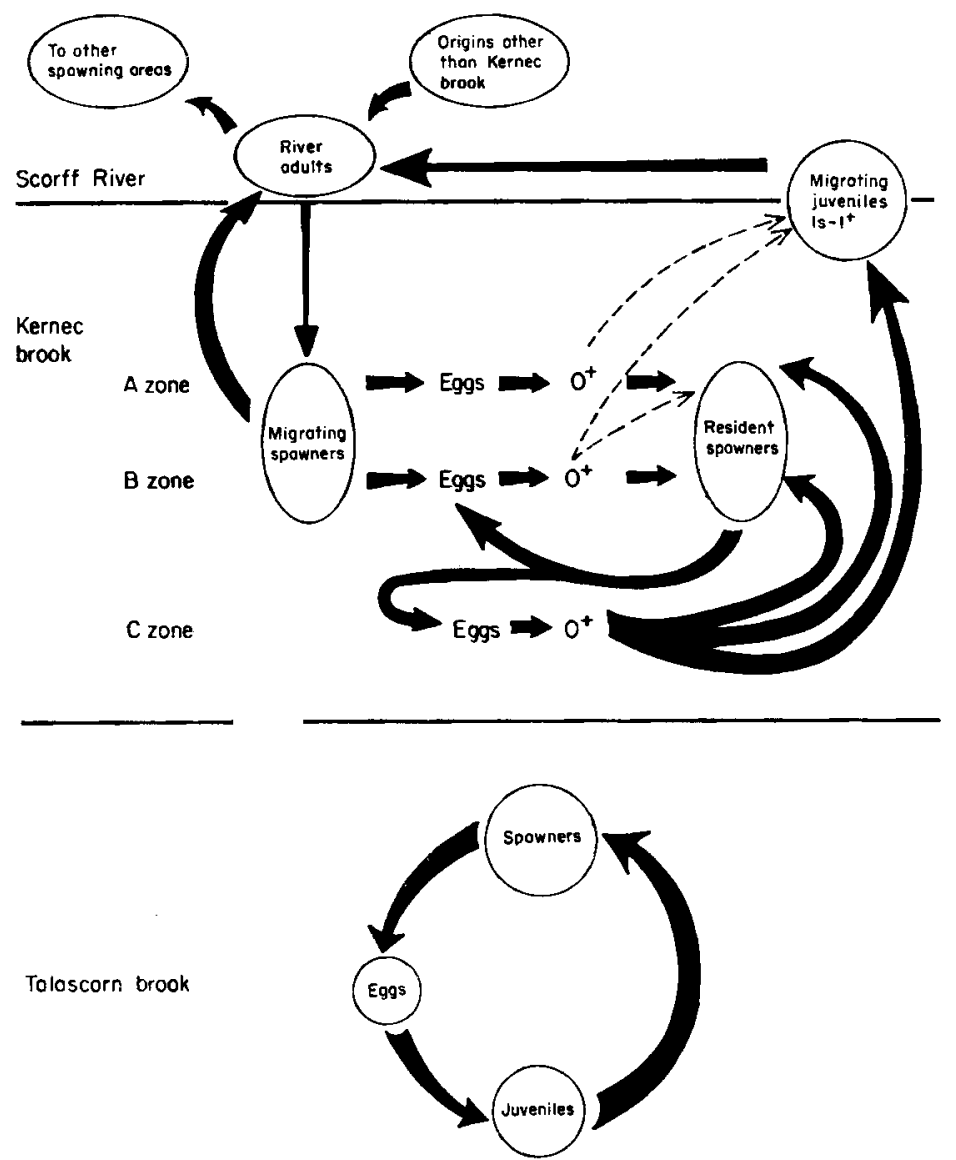

FIG. 4. Schematic representation of colonization strategy of brown trout population in a brook and its tributary.

groups was underestimated, because (a) in spite of the efficiency of electrofishing in autumn $1983(88 \%)$, some $0+$ trout present in zones $A$ and $B$ were not caught and marked; (b) the $0+$ fish caught in zone $C$ were not fin-clipped while the fin-clipping made on the fish of zones A and B could have decreased their survival rate (Nicola \& Cordone, 1973; Mears \& Hatch, 1976); (c) a loss of tags (estimated at up to 10\% from data of double marking) and possible errors of mark reading (regeneration of fins). However, these considerations are not sufficient to explain the behavioural differences according to the geographical origin.

So, migrating juveniles came principally from the upper part of Kernec brook (zone C). As, each year, most of them $(>90 \%)$ are one summer old, the recruitment of juveniles to the river is strongly related to successful spawning in the upstream reaches which are mainly used by resident spawners. There would always be a recruitment of juveniles to the river even if migrating spawners could not run upstream in the brook (cf. Huet \& Timmermans, 1979). 0+ fish produced in the upper part of the brook contribute also to the composition of the resident $1+$ population. This migration of $0+$ fish from the upper reaches does not appear to be dependent on annual conditions, since the total number of 1 -year-old migrating 
and resident trout is always larger than the number of $0+$ trout produced in zone $A$ and B (Table III).

The $0+$ trout present in zones A and B are much more sedentary than those of zone $\mathrm{C}$. In zone $\mathrm{B}$ we observed a significant correlation between the number of $1 \mathrm{~s}$ and $0+$ trout and a higher percentage of recapture by trapping than by electrofishing in zone A. So zone B would contribute more than zone A to river recruitment. Furthermore, some $0+$ coming from that reach colonize the downstream part of the brook. For zone A, the percentage of marked $0+$ trout recaptured in zone $B$ was very low. Further, there was a strong correlation between the numbers of $0+$ and $1+$ individuals. Thus, it was demonstrated that there is a stability of the trout population as early as 1 year old, especially in this downstream part of the brook.

Emigration processes of $0+$ trout from spawning or nursery areas to lower reaches has been observed previously (Solomon \& Templeton, 1976; Libosvarsky, 1977; Milner et al., 1978, 1979; Mortensen, 1979). The upper part of the brook (zone $\mathrm{C}$ ) had a higher density of $0+$ fish than zones $\mathrm{A}$ and $\mathrm{B}$, because the habitat is very favourable to this age class and unfavourable to the older fish (Bohlin, 1977; Baglinière \& Champigneulle, 1982). This segregation decreases possible predation (Egglishaw, 1967; Egglishaw \& Shackley, 1977). Furthermore, there is a low density of secondary species compared to the lower part of brook (Baglinière, 1979). At the beginning of autumn and during winter and spring, $0+$ trout run downstream in large numbers to meet the need for larger territories (Allen, 1969; Kennedy \& Fitzmaurice, 1971; Mortensen, 1977, 1982; Milner et al., 1978). During migration, these fish do not find enough free territory. Individuals of the same age resident in the lower part have not yet migrated, or will not migrate, because they can obtain large enough territories in their brood zone in relation to a greater water depth (Otto, 1976; Baglinière \& Champigneulle, 1982). So juveniles coming from the head-water area would migrate to the river in large numbers.

Though growth seems to influence the general process of emigration by the presence of new territorial and trophic requirements, there is probably no autumn size threshold for migration, as observed in Atlantic salmon, Salmo salar L. (J. L. Baglinière \& G. Maisse, unpubl. data).

The sex ratio in favour of females in migrating juvenile trout obtained in 1983 seems unusual. This is common among sea trout (Campbell, 1977; Le Cren, 1985) but has also been observed amongst brown trout and discussed (Crisp et al., 1984). However, the sex ratio changed according to the migration year and did not appear to differ between migrating and resident juvenile populations. More data are necessary to understand the influence of this feature in the process of emigration in relation to age and migratory behaviour (Le Cren, 1985).

Small numbers of $2 \mathrm{~s}$ migrating fish suggest little movement or stability of population after the $1+$ stage, as observed by Taube (1974), Mense (1975), Solomon \& Templeton (1976), Milner et al., (1978, 1979) and Harcup et al. (1984).

\section{INFLUENCE OF TALASCORN BROOK}

During the study period, the population of trout in Talascorn brook was isolated: no migrating juvenile or spawner was trapped. In the latter case, the absence of attraction at spawning time must be related to lack of floods, a necessary condition for the upstream run of spawners (Baglinière et al., 1987). The absence of the 
contribution of the brook in juvenile recruitment is also suggested by the strong relationship between production of $0+$ and $1+$ age classes. So Talascorn brook could not act as a nursery area.

\section{v. CONCLUSIONS}

The present work and those of Maisse et al. (1987) and Baglinière et al. (1987) lead to a suggested colonization strategy of the brown trout population in a tributary-river system. There are four main aspects:

1. separation of the resident and migrating populations between different spawning areas, the first in the upstream part (zone $\mathrm{C}$ and above) and the second in the downstream part (zone A), with overlapping of these spawning areas being of variable importance in the middle part of the brook (zone B);

2. recruitment of migrating juveniles to the river is brought about mainly by the emigration of $0+$ trout produced in the head-waters of the brook (zone $\mathrm{C}$ and above); $0+$ trout produced in the three zones contribute to the population of $1+$ resident spawners in the brook;

3. some migrating spawners ( $22 \%$ ) come from migrating juveniles, mainly after 6 months for males and $1 \frac{1}{2}$ years for females, in the river;

4. almost all the resident spawners do not leave the brook often spawning.

So Kernec brook is not only a reproduction area for river spawners, as is often observed in systems where a tributary feeds a lake or sea (Campbell, 1957, 1971; Stuart, 1957; Kennedy \& Fitzmaurice, 1971; Keranen et al. 1974; Thorpe, 1974; Treasurer, 1976; Craig, 1982; Elliott, 1984,1985). The colonization strategy of trout in Kernec brook is nearer to that observed by Campbell (1977) in his study on brown and sea trout populations of the R. Tweed. Interaction between resident and migrating trout populations can be summarized (Fig. 4) as: juvenile issue from migrating spawners become mainly $1+$ and older resident spawners; juveniles coming from the resident population contribute partially or fully to recruitment of migrating juveniles, a lot of them coming back to the brook as migrating spawners, and some of them becoming resident spawners. Talascorn brook seems to have no influence on this model, although previous observations have shown that this brook could contribute to juvenile recruitment to the river when the dynamics of the tributary river system were strongly disturbed (drying of head-water areas of Kernec brook in 1976).

This study was carried out under the 'INRA-Ministère de l'Urbanisme et du Logement no 2527A' convention. Technical assistance was given by $\mathrm{H}$. Peron. Electrofishing censuses were done in collaboration with the water bailiff of the West Provincial Delegation of the Fishing Superior Council within field teaching in the "Ecole Nationale Supérieure d'Agronomie de Rennes'.

\section{References}

Allen, K. R. (1969). Limitations on production in salmonid population in streams. In Symposium on Salmon and Trout (T. G. Northcote, ed.) pp 3-20. Vancouver: University of British Coloumbia Press. 
Baglinière, J. L. (1979). Les principales populations de poissons sur une rivière à salmonides de Bretagne-Sud, le Scorff. Cybium 7, 53-74.

Baglinière, J. L. \& Champigneulle, A. (1982). Densité des populations de truite commune (Salmo trutta L.) et de juvéniles de saumon atlantique (Salmo salar L.) sur le cours principal du Scorff (Bretagne): préferendums physiques et variations annuelles (1976-1980). Acta Oecologica Oecol. Applic 3, 241-256.

Baglinière, J. L., Champigneulle, A. \& Nihouarn, A. (1979). La fraie du saumon atlantique (Salmo salar L.) et de la truite commune (Salmo trutta L.) sur le bassin du Scorff. Cybium 7, 75 96.

Baglinière, J. L., Maisse, G., Le Bail, P. Y. \& Prevost, E. (1987). Dynamique de population de truite commune (Salmo trutta L.) d'un ruisseau breton (France): les géniteurs migrants. Acta Oecologica Oecol. Applic. 8, 201-205.

Bohlin, T. (1977). Habitat selection and intercohort competition of juvenile sea-trout, Salmo trutta. Oikos 29, 112-117.

Campbell, R. N. (1957). The effect of flooding on the growth rate of brown trout in Loch Tummel. Freshwat. Salmon Fish. Res. No.14. 7 pp.

Campbell, R. N. (1971). The growth of brown trout Salmo trutta L. in northern Scottish lochs with special reference to the improvement of fisheries. J. Fish Biol. 3, 1-28.

Campbell, J. S. (1977). Spawning characteristics of brown trout and sea trout, Salmo trutta L., in Kirk Burn, River Tweed, Scotland. J. Fish Biol. 11, 217-229.

Chapman, D. W. (1966). Food and space as regulators of salmonid populations in streams. Am. Nat. 913, 345-357.

Craig, J. F. (1982). A note on growth and mortality of trout, Salmo trutta L., in afferent streams of Windermere. J. Fish Biol. 20, 423-429.

Crisp, D. T., Mann, R. H. K. \& Cubby, R. P. (1984). Effects of impoundment upon fish populations in afferent streams at Cow Green Reservoir. J. Appl. Ecol. 21, 739-756.

Egglishaw, H. J. (1967). The food, growth and population structure of salmon and trout in two streams in the Scottish Highlands. Freshwat. Salmon Fish. Res. No. 38. 32 pp.

Egglishaw, H. L. \& Shackley, P. E. (1977). Growth, survival and production of juvenile salmon and trout in a Scottish stream, 1966-75. J. Fish Biol. 11, 647-672.

Elliott, J. M. (1984). Numerical changes and population regulation in young migratory trout, Salmo trutta, in a Lake District stream, 1966-83. J. Anim. Ecol. 53, 327-350.

Elliott, J. M. (1985). Population regulation for different life stages of migratory trout, Salmo trutta, in a Lake District stream, 1966-83. J. Anim. Ecol. 54, 617-638.

Euzenat, G. \& Fournel, F. (1976). Recherches sur la truite commune (Salmo trutta L.) dans une rivière de Bretagne, le Scorff. Thèse 3éme cycle Faculté des sciences, Université de Rennes. $230 \mathrm{pp}$.

Harcup, M., Williams, R. \& Ellis, D. M. (1984). Movements of brown trout, Salmo trutta L., in the River Gwyddon, South Wales. J. Fish Biol. 24, 41 5-426.

Huet, M. \& Timmermans, J. A. (1979). Fonctionnement et rôle d'un ruisseau frayères à truites. Trav. Stat. Rech. Eaux Forêts Groenedaal Sér. D, No. 48.31 pp.

Kennedy, M. \& Fitzmaurice, P. (1971). Growth and food of brown trout (Salmo trutta L.) in Irish waters. Proc. R. Irish Acad. 71, 269-352.

Keränen, M., Ellonen, T. \& Lind, E. A. (1974). Kudulle nonsevan taimenen, Salmo trutta L., ominaisunksista ja populaatiora Kenteesta oulankajoen Kiutakön Käällä (Summary: Characteristics and population structure of the brown trout, Salmo trutta L., in the Oulankajoki river at Kiutaköngäs). Ichtyol. Fennica Borealis 1, 1-66.

Le Cren, E. D. (ed.) (1985). The Biology of Sea Trout (Summary of Symposium Oct. 1984). Pitlochry: Atlantic Salmon Trust. $41 \mathrm{pp}$.

Libosvarsky, J. (1977). Spatial stability of brown trout in stream action. Folia Zool. 26, 61-78.

Maisse, G., Baglinière, J. L. \& Le Bail, P. Y. (1987). Dynamique de la population de truite commune (Salmo trutta L.) d'un ruisseau breton (France): les géniteurs sédentaires. Hydrobiologia 148, 123-130.

Mears, H. C. \& Hatch, R. W. (1976). Overwinter survival of fingerling brook trout with single and multiple fin clips. Trans. Am. Fish. Soc. 105, 669-674. 
Mense, J. B. (1975). Relation of density to brown trout movement in a Michigan stream. Trans. Am. Fish. Soc. 104, 688-695.

Milner, N. J., Gee, A. S. \& Hemsworth, R. J. (1978). The production of brown trout, Salmo trutta, in tributaries of the upper Wye, Wales. J. Fish Biol. 13, 599-612.

Milner, N. J., Gee, A. S. \& Hemsworth, R. J. (1979). Recruitment and turnover of populations of brown trout, Salmo trutta, in the Upper River Wye, Wales. J. Fish Biol. 15, $211-222$.

Mortensen, E. (1977). Density-dependent mortality of trout fry (Salmo trutta L.) and its relationship to the management of small streams. J. Fish Biol. 11, 613-617.

Mortensen, E. (1979). Population dynamics, regulation and production of stream salmonids. In The Use of Ecological Variables in Environmental Monitoring. Ntn. Swedish Envir. Protect. Bd Rep. PMU5 t, 220-227.

Mortensen, E. (1982). Production of trout, Salmo trutta, in a Danish stream. Envir. Biol. Fish. 7, 349-356.

Nicol, S. J. \& Cordone, A. J. (1973). Effects of fin removal on survival and growth of rainbow trout (Salmo gairdneri) in a natural environment. Trans. Am. Fish. Soc. 102, $735-758$.

Nihouarn, A. (1983). Etude de la truite commune (Salmo trutta L.) dans le bassin due Scorff (Morbihan). Démographie, reproduction, migrations. Thèse 3ème cycle, Faculté des sciences, Université de Rennes. 73 pp.

Otto, C. (1976). Size, growth, population density and food of brown trout, Salmo trutta L., in two sections of a south Swedish stream. J. Fish Biol. 8, 477-488.

Solomon, D. J. \& Templeton, R. G. (1976). Movements of brown trout, Salmo trutta L., in a chalk stream. J. Fish Biol. 9, 411-423.

Stuart, T. A. (1957). The migrations and homing behaviour of brown trout. Salmon Fish. Res. No. 18. 27 pp.

Taube, C. M. (1974). Stability of residence among brown trout and rainbow trout in experimental sections of the Platte river. Michigan Dept Nat. Resources Fish. Div. Fish. Res. Rep. No. 1817. 20 pp.

Thorpe, J. E. (1974). The movements of brown trout, Salmo trutta (L.), in Loch Leven, Kinross, Scotland. J. Fish Biol. 6, 153-180.

Treasurer, J. W. (1976). Age, growth and length-weight relationship of brown trout Salmo trutta (L.) in the Loch of Strathbeg, Aberdeenshire. J. Fish Biol. 8, 241-253. 